\title{
高レイノルズ数エルボ管流れにおける熱伝達率に基づく形状係数
}

\author{
恒吉 達矢 ${ }^{* 1}$, 伊藤 高啓*1, 辻 義之*1
}

\section{Geometry factor obtained from wall heat transfer coefficient in high Reynolds number elbow flow}

\author{
Tatsuya TSUNEYOSHI*1 ${ }^{*}$ Takahiro ITO*1 and Yoshiyuki TSUJI ${ }^{* 1}$ \\ ${ }^{* 1}$ Department of Energy Engineering and Science, Nagoya University \\ Furo-cho, Chikusa-ku, Nagoya 464-8603, Japan
}

Received: 31 August 2017; Revised: 30 January 2018; Accepted: 18 February 2018

\begin{abstract}
Flow accelerated corrosion (FAC) is one of the causes for wall thinning mechanisms in carbon steel pipes. Prediction of geometry factor is the key elements for estimation of FAC. Geometry factor is defined as the ratio of wall mass transfer coefficient in the piping systems such as elbow to that in a straight pipe. In this study, geometry factor of the elbow pipe is computed by using large eddy simulation (LES) for $R e=45000,180000$ and 540000. Mass transfer coefficient is evaluated based on the calculations simulating the heat transfer phenomena, instead of the mass transfer. Geometry factors obtained from the heat transfer coefficient by LES are good agreement with experimentally measured values by electrochemical method at $R e=45000$. Geometry factors on the outer side of the elbow are affected by strong shear flow and decrease with increase of $R e$. Geometry factors on inner side become large due to the unsteady swirling flow and they slightly depend on $R e$. The maximum of geometry factors are found on inner side near elbow outlet and their values are $2.38,2.04,1.76$ for $R e=45000,180000,540000$, respectively.
\end{abstract}

Keywords : Flow accelerated corrosion, Mass transfer, Heat transfer, Geometry factor, Elbow, LES

\section{1. 緒言}

原子力発電プラントの炭素鋼配管における減肉事象の一因として, 流れ加速型腐食 (Flow Accelerated Corrosion, 以下 FAC と略す) には十分な注意を要する.FAC とは配管内で生じる複雑流動により，炭素鋼配管内壁からの鉄 イオンの溶解および拡散が促進され，減肉が進行する現象である(Dooley and Chexal, 2000). FAC の根本的な要因 は腐食であり, キャビテーション等の流体の機械的作用による減肉とは区別される. FAC は流れが複雑な乱流と なる個所で生じ, オリフィスやエルボ等の種々の配管要素において FAC による減肉が発生していることが報告さ れている(日本機械学会, 2014). 原子力プラントの高経年化が進む中で, 配管安全管理のために減肉予測の精度向 上が強く求められている. FAC は配管内壁から流体中への物質伝達現象であり, 流体力学的な作用の影響は, 壁 面からの鉄イオンの溶出速度を表す物質移行係数として定量的に評価することができる.減肉予測の観点からは, 対象とする配管要素における物質移行係数 $k_{c}$ と直円管における物質移行係数 $k_{c 0}$ の比として定義される形状係数 $k_{c} / k_{c 0}$ として相対的な FAC の危険性を評価することが有用である.

著者らはオリフィス下流およびエルボ管流れを対象に数值計算ならびに電気化学実験により形状係数の算出を 行なった(恒吉他, 2017). 数值計算では, LES(Large Eddy Simulation)により流動場および鉄イオンの濃度場を模擬 した温度場の計算を行い，熱伝達率に基づく形状係数を算出した．実験では，作用極として点電極を用いた対流 ボルタンメトリーにより物質移行係数を測定して形状係数を導出した。その際，試験部配管を伝導体を用いて作

No.17-00387 [DOI:10.1299/transjsme.17-00387], J-STAGE Advance Publication date : 27 February, 2018

本論文は，第22回動力・エネルギー技術シシポジウム 講演論文集(2017), No.F133の掲載内容に基づいた論文である.

*1 正員, 名古屋大学 工学研究科 (

E-mail of corresponding author: t-tsuneyoshi@energy.nagoya-u.ac.jp 
成し，試験部内壁も作用極として機能させることで，測定点電極上だけではなく内壁全体での物質伝達を生じさ せた全面電極条件における物質移行係数の測定を行った。その結果，点電極を単独で作用させた場合と壁面全面 に通電した場合の形状係数は定性的に大きく異なることを明らかにした．また，数值計算により求めた熱伝達率 に基づく形状係数と全面電極条件で測定した形状係数は定量的に一致することを示した.

エルボ管では，非定常性の強い 3 次元的に複雑な流れ(結城他, 2004, Tanaka and Ohshima, 2012, Vester et al., 2016) が生じるだけでなく, 流れ場にレイノルズ数依存性(河村他, 2002, 岩本他, 2010)が存在することが知られている. 著者らのエルボ管流れを対象とした電気化学実験(恒吉他, 2017)は, $R e=4.5 \times 10^{4}$ という条件で実施しており, レイノルズ数が $10^{6}$ オーダーとなるプラント実機配管の形状係数予測として実験值をそのまま適用することはで きない. エルボ管における圧力損失係数のレイノルズ数依存性(Shiraishi et al., 2006)を考慮すると, エルボ管形状 により多少異なるが, 概ねレイノルズ数が $4 \times 10^{5}$ まではエルボ管流れに強いレイノルズ数依存性が存在し, レイ ノルズ数が $4 \times 10^{5}$ を超えるとエルボ管形状より一意に定まる流れが形成されると期待される. そのため, Ono ら はレイノルズ数依存性が残っている条件としてRe $=1.8 \times 10^{5}$, 十分な高レイノルズ数条件として $R e=5.4 \times 10^{5}$ の 2 条件で PIV による流動場測定を行なっている(Ono et al., 2011). 電気化学実験で用いた室内実験ループにおい て, $10^{5}$ オーダーのレイノルズ数を実現することは困難である. そこで, 本研究では電気化学実験に合わせたRe $=$ $4.5 \times 10^{4}$ の数值計算(恒吉他, 2017)に加えて, 実機プラント配管を視野に入れた高レイノルズ数条件としてRe= $1.8 \times 10^{5}, 5.4 \times 10^{5}$ における数值計算を実施し，エルボ管の形状係数を明らかにすることを目的とする.

LES 計算においては壁面近傍の計算手法に関して, 密なメッシュを配置し微細な乱流構造まで直接的に解像す る方法と，比較的荒いメッシュを用いつつ壁関数の適用や RANS(Reynolds Averaged Navier-Stokes) とのハイブリッ ドモデルにより計算する方法がある. 熱伝達や物質伝達を対象とした LES では, 計算精度が高く, 詳細なスカラ 一輸送の解析が可能な前者の方法が望まれる．ただし，解析しようとする壁面近傍の渦スケールは，レイノルズ 数の増加とともに小さくなる. また, 水の熱伝達のような高プラントル数条件においては, 温度場の変動スケー

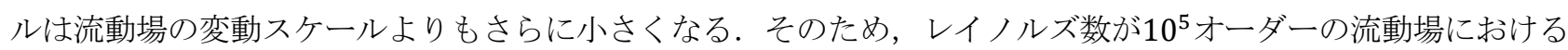
熱伝達の LES 計算のためには, 数億セルのメッシュを必要とし, スーパーコンピュータを用いた大規模並列計算 が必須となる．平行平板間乱流のような典型的壁乱流を対象にインハウスコードを用いた大規模計算は既に行わ れているものの, 工学的な複雑流動場を対象に大規模計算が実施された例はほとんどない. 工学的な流動場計算 では，商用コードが広く利用されているが，大規模な並列計算に対してはライセンスに関連した制約が多く容易 ではない，本研究では，並列計算時のライセンスの制限がないオープンソースコードの OpenFOAM を用いるこ とで，複雑流動場を対象とした並列数が 1000 を超える規模での LES 計算に基づく解析を実現した.

\section{2. 数値計算方法}

\section{$2 \cdot 1$ LES の計算条件}

エルボ管流れを対象に，LESにより流動場ならびに温度場の非定常計算を実施した．LES の計算条件を表 1 に 示す．計算条件は，管直径 $D$ および断面平均流速 $V_{z 0}$ を用いて定義されるレイノルズ数 $R e\left(=V_{z 0} D / v\right)$ が $4.5 \times 10^{4}$ とした既報の計算(恒吉他, 2017) と同様であり，概要を以下に記す．計算には数值流体のオープンソースコードで ある OpenFOAM(version 2.2.1)を用いた(OpenCFD, 2015). 本計算では, 鉄イオンの濃度場を模擬したスカラー場と して温度場の計算を行っている. OpenFOAM の標準ソルバのひとつである pimpleFoam をべースに，パッシブス カラーとして温度場を計算するようにコードの追加および修正をしている. LES の乱流モデルは動的スマゴリン スキーモデル(Germano et al., 1991)を用いた．作動流体は非圧縮性を仮定し，物性值は温度 $300 \mathrm{~K}$ の水として動粘 度 $v$, 熱伝導率 $\lambda$, 温度拡散率 $\alpha$ を定数で与えている. このとき, プラントル数 $\operatorname{Pr}$ は約 5.8 である. サブグリッド スケールの乱流熱拡散の算出に用いる乱流プラントル数 $P r_{t}$ は 0.9 とした. レイノルズ数は $4.5 \times 10^{4}$ に加えて, $1.8 \times 10^{5}, 5.4 \times 10^{5}$ の 3 条件とした．統計処理時間 $t$ はそれぞれ 2.25 秒, 0.54 秒, 0.18 秒である. これは，おおよ そ $V_{z 0} t / D=43$ であり, 計算領域を断面平均流速で 3 回程度流下寸るのに要する時間である. 時間発展は 2 次精 度後退差分を用いた陰解法である. 移流項は制限関数に superbee (Roe, 1985)を用いた TVD スキームを適用した。 拡散項は 2 次精度中心差分である. 図 1 に計算領域の概要を示す．エルボ管の形状は，曲り中心から管軸中心ま での距離で定義される曲率半径が $R_{c} / D=1.5$ の 90 度エルボである. 計算領域は, エルボの上流側, 下流側に $6 D$ 
の長さを設定した。 入口境界には mappedPatch という境界条件を適用し，下流方向長さ $4 D$ の位置の断面における 物理量を参照して入口の值を定めている. これにより, 入口から下流方向長さ $4 D$ の区間は発達乱流を生成するド ライバーとして機能する.

\section{$2 \cdot 2$ 温度場の計算条件および熱伝達率に基づく形状係数の算出方法}

温度場の計算条件は，水の入口断面における平均温度が $300 \mathrm{~K}$ に対して，壁面は $\Theta_{t w}=310 \mathrm{~K} の 一$ 様な等温加 熱条件である，入口境界条件の mappedPatch において断面平均温度が $300 \mathrm{~K}$ にるように補正を行ない，ドライ バー区間において発達した温度場を形成して，エルボ部へ流入させている．温度場計算の結果から，次式により 壁面の熱伝達率 $h$ を求める.

$$
h=\frac{q_{w}}{\Theta_{t w}-\Theta_{t b}}
$$

ここで， $q_{w}$ は加熱壁面における熱流束であり，熱伝導率入と壁面の温度勾配から算出される． $\Theta_{t w}$ は加熱壁面の温 度， $\Theta_{t b}$ は流体のバルク温度である. 本計算では入口管軸中心の温度を $\Theta_{t b}$ として熱伝達率を求めている. 本計算 の温度場は, 鉄イオンの濃度場を模擬しており, 壁面の物理量として熱伝達率 $h$ が物質移行係数 $k_{c}$ に相当する.よ って, 熱伝達率に基づく形状係数は式(2)となる.ここで, 下付きのゼロは円管発達乱流における值を表しており， 本計算ではドライバー部の平均值として求めた.

$$
\frac{k_{c}}{k_{c 0}}=\frac{h}{h_{0}}
$$

\begin{tabular}{|c|c|c|}
\hline Software & \multicolumn{2}{|c|}{ OpenFOAM (2.2.1) } \\
\hline Solver & \multicolumn{2}{|c|}{ Modified pimpleFoam } \\
\hline Turbulent model & \multicolumn{2}{|c|}{ Dynamic Smagorinsky model } \\
\hline \multirow{6}{*}{ Fluid } & \multicolumn{2}{|c|}{ Water $(300 \mathrm{~K})$} \\
\hline & Kinematic viscosity & $v=8.5735 \times 10^{-7} \mathrm{~m}^{2} / \mathrm{s}$ \\
\hline & Thermal conductivity & $\lambda=0.6104 \mathrm{~W} /(\mathrm{m} \cdot \mathrm{K})$ \\
\hline & Thermal diffusivity & $\alpha=1.466 \times 10^{-7} \mathrm{~m}^{2} / \mathrm{s}$ \\
\hline & Prandtl number & $\operatorname{Pr}=v / \alpha=5.847$ \\
\hline & Turbulent Prandtl number & $P r_{t}=0.9$ \\
\hline Time integration & \multicolumn{2}{|c|}{ Implicit unsteady } \\
\hline Transient term & \multicolumn{2}{|c|}{ 2nd-order backward difference scheme } \\
\hline Convection term & \multicolumn{2}{|c|}{ 2nd-order total variation diminishing scheme } \\
\hline Diffusion term & \multicolumn{2}{|c|}{ 2nd-order central difference scheme } \\
\hline \multirow{3}{*}{$\begin{array}{l}\text { Boundary } \\
\text { conditions }\end{array}$} & Inlet & Fully developed \\
\hline & Outlet & Constant total pressure \\
\hline & Wall & Non slip \\
\hline Reynolds number & \multicolumn{2}{|c|}{$\begin{array}{c}R e=V_{z 0} D / v=4.5 \times 10^{4}, 1.8 \times 10^{5}, 5.4 \times 10^{5} \\
\left(V_{z 0}: \text { Cross sectional mean streamwise velocity }\right)\end{array}$} \\
\hline
\end{tabular}

Table 1 Conditions of large eddy simulation in elbow flow. 


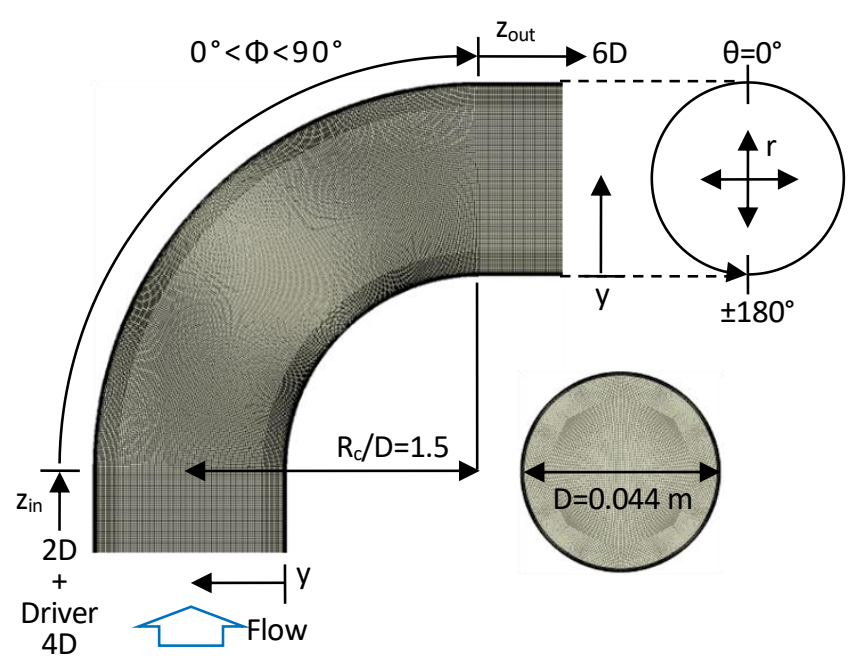

Table 2 Cell size and number of cells.

\begin{tabular}{|c|c|c|c|}
\hline$R e$ & $4.5 \times 10^{4}$ & $1.8 \times 10^{5}$ & $5.4 \times 10^{5}$ \\
\hline$L_{r}^{+}$ & $0.4-35$ & $0.4-33$ & $0.4-55$ \\
$L_{\theta}^{+}$ & 26 & 25 & 25 \\
$L_{z}^{+}$ & 78 & 75 & 75 \\
\hline$N_{r \theta}$ & 8256 & 38304 & 148608 \\
$N_{z}$ & 431 & 1508 & 3948 \\
$N_{\text {total }}$ & $3.56 \times 10^{6}$ & $5.78 \times 10^{7}$ & $5.87 \times 10^{8}$ \\
\hline
\end{tabular}

Fig.1 Mesh adopted for the calculation of elbow flow.

\section{$2 \cdot 3$ 座標系の定義}

図 1 にはポスト処理のために定義した座標系を示した。流れ方向の座標として, エルボ上流ではエルボまでの 距離 $z_{i n}$, エルボ内では曲り角 $\phi$, エルボ下流ではエルボからの距離 $z_{\text {out }}$ を用いる. 円管断面の周方向の角度 $\theta$ はエ ルボ背側を $0^{\circ}$ ，エルボ腹側を $\pm 180^{\circ}$ とする．管軸を含む中央断面において，エルボ腹側壁面をゼロとしたエルボ 背側方向への位置 $y$ を定義する. 下付き添え字の $r, \theta$, zはそれぞれ径方向，周方向，流れ方向を表す.

\section{$2 \cdot 4$ メッシュ条件}

メッシュは図 1 に示した通り, ヘキサメッシュ(6面体セル)を用いた. セルサイズLはレイノルズ数により変え ており, 円管発達乱流における摩擦速度 $u_{\tau}$ を用いた無次元数 $L^{+}\left(=u_{\tau} L / v\right)$ で表した場合に同程度の值となるよう に設定している(表 2). エルボ管流れの熱伝達計算においては, エルボ部で生じる偏流や 2 次流れという比較的大 きなスケールの流動構造とともに，壁面近傍の小さなスケールの流動や熱輸送を適切にとらえる必要がある．レ イノルズ数を増加させた際には，壁面近傍の相対的な流動のスケールは小さくなるが，無次元化したセルサイズ $L^{+}$等しくすることで, 熱伝達計算の精度を一定に保つことができる. $L^{+}$の值の選定については次項で詳しく述 べる. 表 2 には円管断面のセル数 $N_{r \theta}$ および流れ方向のセル数 $N_{z}$ を示した. 計算領域全体のセル数 $N_{\text {total }}$ は, レイ ノルズ数 $4.5 \times 10^{4}, 1.8 \times 10^{5}, 5.4 \times 10^{5}$ に対してそれぞれ $3.56 \times 10^{6}, 5.78 \times 10^{7}, 5.87 \times 10^{8}$ である.

\section{$2 \cdot 5$ エルボ管流れにおける熱伝達計算のメッシュ解像度依存性}

レイノルズ数が $4.5 \times 10^{4}$ のエルボ管流れを対象として, 表 3 に示寸セルサイズの異なる 4 条件で計算を行な い, 計算精度のメッシュ解像度依存性を検討した. Case 1 のメッシュが最も粗く, Case 4 が最も細かい. Case 3 が本計算で用いたセルサイズである. Case 1 から Case 2 においてセルサイズを $3 / 4$ 倍, Case 2 から Case 3 および Case 3 から Case 4 においてセルサイズを $2 / 3$ 倍程度細かくしている．ただし，壁面近傍の壁垂直方向のメッシュ が粗いと, 計算精度が著しく低下寸るため, 全ての Case で壁面第 1 層セルの厚さは $L_{r}{ }^{+}=0.4$, 壁垂直方向への 伸長率は 1.2 としている. これは, プラントル数を用いて表される温度場計算における相対的なセルサイズ $L^{++}\left(=\operatorname{Pr}^{1 / 2} L^{+}\right)$において, 壁面第 1 層セルの厚さがおおよそ $L_{r}{ }^{++}=1$ となり, 壁乱流の LES（森西他, 2000） と 比較して十分な解像度を有している。

図 2 に計算結果としてエルボの背側 $\left(\theta=0^{\circ}\right)$ と腹側 $\left(\theta=180^{\circ}\right)$ の線上における熱伝達率をヌセルト数 $N u$ で示す. エルボの背側では, 主に流れ方向流速の偏りにより熱伝達が増加するが, 熱伝達に影響する流動構造のスケール が大きいため, 計算精度のメッシュ解像度依存性は小さい, 一方, エルボの腹側出口周辺では, 2 次流れに起因 する非定常性の強い流れにより熱伝達が促進されるが，熱輸送に寄与寸る流動構造のスケールが小さい，そのた め, メッシュが粗くなると, ヌセルト数の最大值や最大となる位置を見誤る. Case 3 の結果は Case 4 に対して, わずかにヌセルト数の值を過小評価しているが，分布形状はよく一致している．よって， Case 3 のメッシュは， 
エルボ腹側の比較的スケールの小さな流動構造によるスカラー輸送の過程を計算可能な程度に細かく，エルボ管 流れの熱伝達現象を解析するのに適切なメッシュ解像度を有していると考えられる.

Table 3 Validation conditions for elbow flow at $R e=4.5 \times 10^{4}$.

\begin{tabular}{|c|c|c|c|c|}
\hline & Case 1 & Case 2 & Case 3 & Case 4 \\
\hline$L_{r}{ }^{+}$ & $0.4 \sim 59$ & $0.4 \sim 44$ & $0.4 \sim 35$ & $0.4 \sim 25$ \\
$L_{\theta}{ }^{+}$ & 51 & 38 & 26 & 17 \\
$L_{z}{ }^{+}$ & 156 & 117 & 78 & 52 \\
\hline$N_{\text {total }}$ & $7.46 \times 10^{5}$ & $1.52 \times 10^{6}$ & $3.56 \times 10^{6}$ & $8.47 \times 10^{6}$ \\
\hline
\end{tabular}

(a)

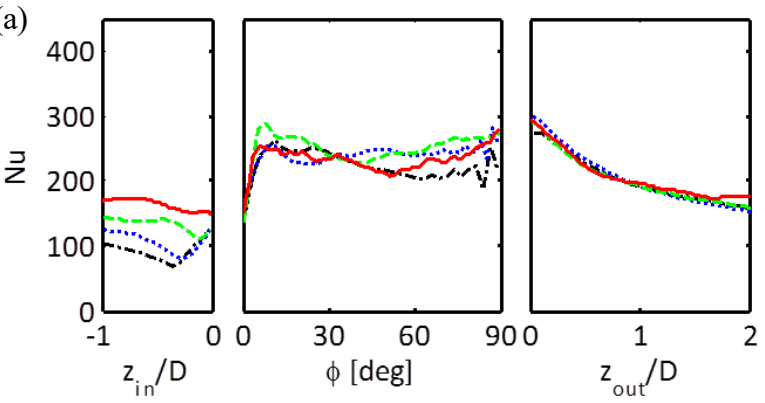

(b)

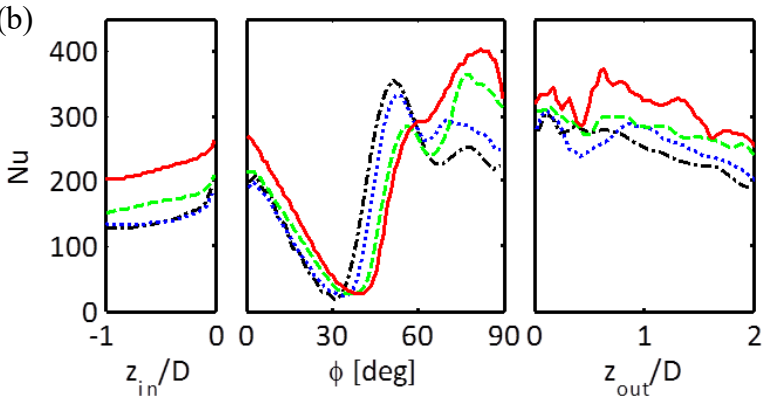

Fig. 2 Effect of mesh resolution on Nusselt number in elbow flow for $R e=4.5 \times 10^{4}$, (a) $\theta=0^{\circ}$, (b) $\theta=180^{\circ}$. Mesh resolution is shown in table $3, \ldots \ldots$ Case 1 , : Case 2,

Case 3, : Case 4

\section{2 -6 OpenFOAM を用いた大規模並列計算}

OpenFOAM におけるメッシュの取り扱いは非構造格子であり，メッシュは通し番号であるラベルで管理される. OpenFOAM の標準的なコンパイルでは，ラベルは 32 ビット整数が用いられる. 32 ビット整数で表現できる最大 の整数值は $2^{32}-1$ (約 21 憶)である. 数億セルのメッシュの作成を試みると，フェイス数が数十億となり，32 ビ ット整数のラベルでは表現し得なくなる，そのため，数億を超えるセルのメッシュを OpenFOAM で扱うために は，ラベルに 64 ビット整数を用いる必要がある. OpenFOAM のメジャーバージョンが 2 までは，wmakeディレ クトリ配下の general ファイルにおいて, DFOAM_LABEL64 のフラグを追加してコンパイルすることで，メッシ ユラベルは 64 ビット整数となる.メジャーバージョンが 3 以降は，WM_LABEL_SIZE=64 と環境変数に明示する ことで，64ビット整数のラベルが使用できる.

本計算には, 名古屋大学のスーパーコンピュータシステムである Fujitsu PRIMERGY CX400 を用いた. ノード 間並列には Intel MPI（version 4.1.1）を用い，レイノルズ数が $4.5 \times 10^{4}, 1.8 \times 10^{5}, 5.4 \times 10^{5}$ に対して，並列数は それぞれ 48, 384, 1344 とした. メッシュ数が数億セル，並列数が 1000 を超える程度になると，Scotch ライブラ リ等を用いた自動領域分割では，分割された領域間のフェイス数や，1つの分割領域に接続する他の分割領域の 数が増加し, 並列化効率が大幅に低下する. 本計算では, cellDecomposition ファイルを用いて各セルの processor 番号を明示し，領域分割を手動で行うことで，分割領域間のフェイス数や接続する分割領域の数を抑制し，並列 化効率の向上を図った. 領域分割や計算結果の結合, 結果の可視化といったプリポスト処理には, 大規模共有メ モリシステムである SGI UV2000を用いた.

\section{3. 結果および考察}

\section{$3 \cdot 1$ エルボ管の平均流動場}

図 3 に管軸を含むエルボ管中央断面における, 時間平均した流れ方向流速のコンターを示す. 図 4 にはエルボ 入口からエルボ下流にかけてのそれぞれの位置における，壁垂直方向分布を左から順にプロットしている．流れ 方向流速は断面平均流速 $V_{z 0}$ により無次元化している. エルボの入口においては, 主流部の高速領域はエルボ腹側 に偏っている. エルボ内で腹側からの流れの剥離とともに, 高速領域は管軸中心へ移り, エルボを通過した後は 背側への偏流となる. 剥離した流れと壁面に挟まれた腹側出口周辺には，低速領域が形成される．本計算の曲率 
半径 $R_{c} / D=1.5$ の条件では, 流れ方向の平均流速に逆流はみとめられない.レイノルズ数の増加により, 流れの 剥離点は下流側に移動し，腹側の低速領域も小さくなる傾向にある．そのため，エルボ内ではレイノルズ数が低 い程, 背側への流速の偏りが大きくなり, 背側壁面の速度せん断も強くなる. $R e=4.5 \times 10^{4}$ の場合は, エルボ出 口において背側の壁面せん断応力が最も大きくなる．レイノルズ数が増加すると，エルボを通過後に背側への偏 流が強く表れるようになる. $R e=5.4 \times 10^{5}$ では，おおよそ $z_{\text {out }} / D=2$ において背側の壁面せん断応力は最大と なる. 本計算で求めた流速分布は, 同じ曲率半径 $\left(R_{c} / D=1.5\right)$ とレイノルズ数 $\left(R e=1.8 \times 10^{5}, 5.4 \times 10^{5}\right)$ を対象 とした Ono ら(Ono et al., 2011)の PIV 測定の結果と概ね一致している. 特に, 流れの剥離によって形成される高速 領域と低速領域の境目の位置はよく一致している. エルボ出口 $\left(z_{\text {out }} / D=0\right)$ の分布を比較すると, 高レイノルズ 数条件における本計算結果および Ono らの測定結果は，ともに管軸中心の近傍において流速が $V_{z} / V_{z 0}=1.1$ 程度 で壁垂直方向に比較的平坦な分布となっている．また，壁垂直方向位置がおおよそ $y / D<0.2$ の範囲が低速領域 となっている点も共通している．ただし，低速領域における流速の值については，本計算結果では $V_{z} / V_{z 0}=0.55$ 程度となっているが, Ono らの測定結果は $V_{z} / V_{z 0}$ が 0.8 よりも高い值を示しており異なっている. この差異は, エ ルボへの流入条件に関して, 本計算ではドライバー部を設けて完全発達乱流としているのに対して, Ono らの測 定では助走距離を $10 D$ と短く設定しており流れが発達段階にあるという違いによって生じたものと考えられる.

(a)

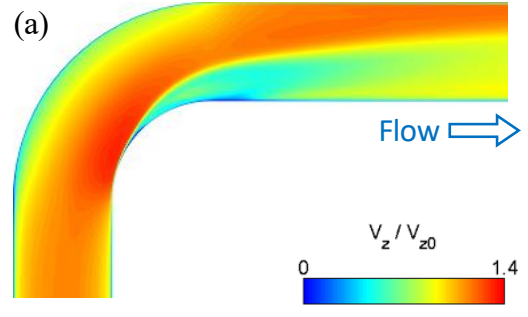

(b)

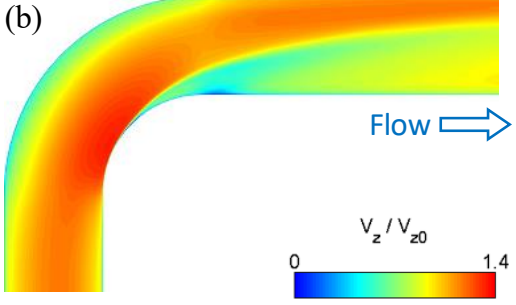

(c)

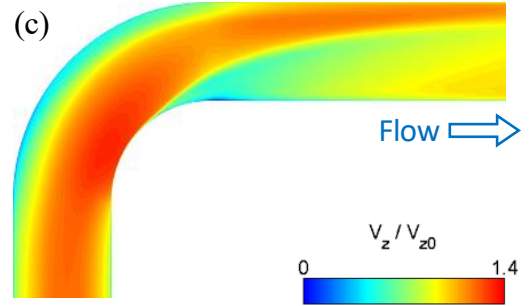

Fig.3 Contour of mean streamwise velocity in a mid-plane of the elbow, (a) $R e=4.5 \times 10^{4}$, (b) $R e=1.8 \times 10^{5}$, (c) $R e=5.4 \times 10^{5}$. As Reynolds number increases, the separation point moves to the downstream.

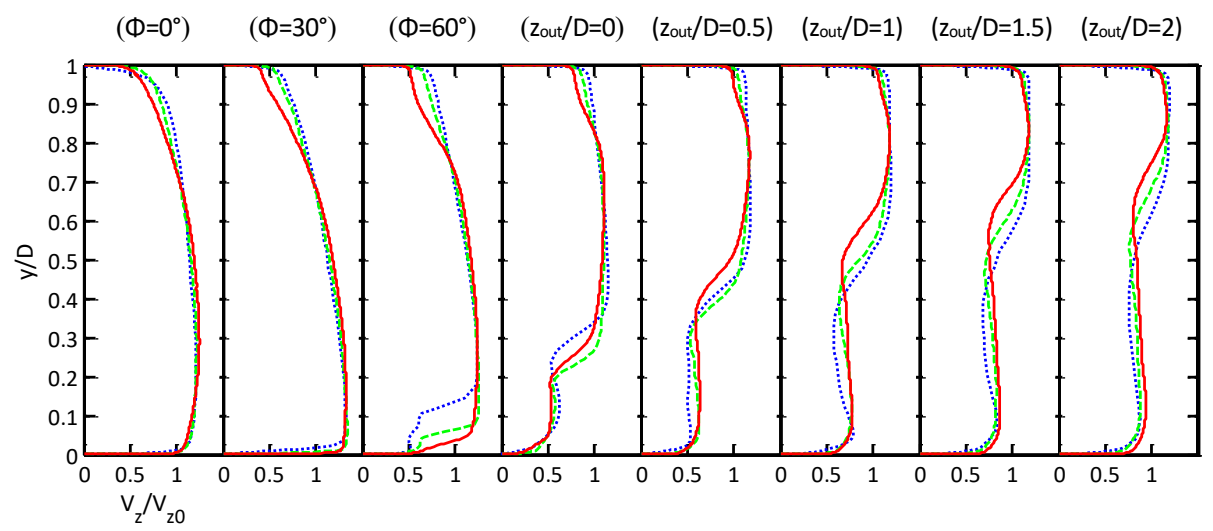

Fig.4 Profiles of mean streamwise velocity at several streamwise positions. . $R e=1.8 \times 10^{5}$, $R e=5.4 \times 10^{5}$.

$R e=4.5 \times 10^{4}$

\section{$3 \cdot 2$ エルボ出ロにおける瞬時の 2 次流れ}

図 5 にRe $=5.4 \times 10^{5}$ の場合のエルボ出口断面における瞬時の 2 次流れを，径方向流速 $v_{r}$ と周方向流速 $v_{\theta}$ を合 わせた速度 $v_{r \theta}=\sqrt{v_{r}^{2}+v_{\theta}^{2}}$ のベクトルとコンターで示す. 図 5 の(a)と(b)は壁面に沿う腹側への時計回りまたは 反時計回りのどちらかの 2 次流れが特に強くなった瞬間を示している.この両方向の旋回流は強弱が周期的に入 れ替わるが，どちらか片方の旋回流が他方に卓越している時間は短く, 時系列データの中で占める割合は低い. 時系列データの中の多くで, 図 5(c)のように左右から同程度の強さの 2 次流れが腹側に流れ込み，細かな擾乱が 腹側壁面近傍で発生する様子が確認できた． $R e=4.5 \times 10^{4}, 1.8 \times 10^{5}$ の場合も，生じる乱れのスケールは異な るものの, 2 次流れの様相はRe $=5.4 \times 10^{5}$ の場合と同様である. 
(a)

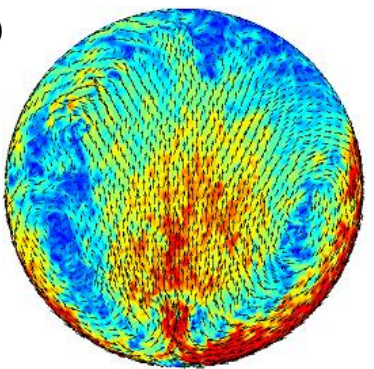

(b)

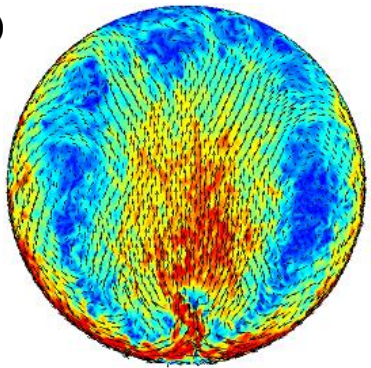

(c)

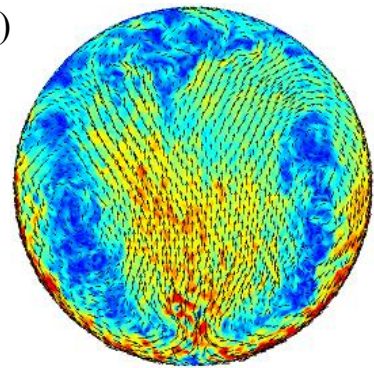

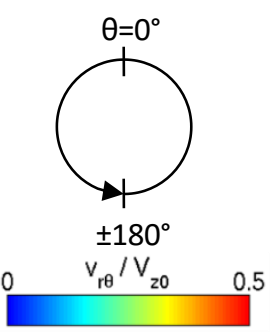

Fig.5 Instantaneous swirling flow in a cross section of the elbow outlet for $R e=5.4 \times 10^{5}$. (a) Strong secondary flow in clockwise or (b) counter-clockwise appeared intermittently. (c) Usually, secondary flow in both directions of the same strength occurred.

\section{$3 \cdot 3$ 乱流エネルギー分布}

エルボ出口断面における乱流エネルギー分布を図 6 に示す。眓 5 に示した 2 次流れにより，エルボ出口の腹側 では特に高い乱流エネルギーが生じる. $R e=4.5 \times 10^{4}$ の場合は，腹側の乱流エネルギーが高い領域の周方向へ の広がりが大きい.レイノルズ数が増加すると，乱流エネルギーが高い領域は狭まる。図 7 にはエルボ管中央断 面における乱流エネルギーのコンターを示す．腹側の乱流エネルギーが高い領域の流れ方向への広がりもRe = $4.5 \times 10^{4}$ の場合が最も大きく, レイノルズ数の増加とともに空間的広がりは縮小する. 乱流エネルギーの最大值 も $R e=4.5 \times 10^{4}$ が最も高い. レイノルズ数の増加に対して乱流エネルギーの最大值は減少傾向にあるが， Re = $1.8 \times 10^{5}$ と $R e=5.4 \times 10^{5}$ の差異は小さい.

(a)

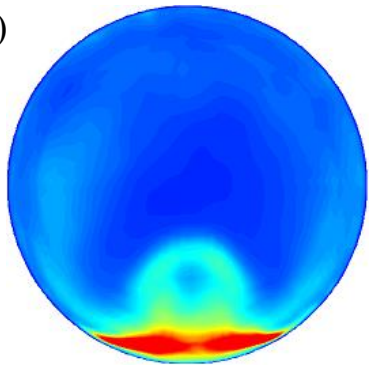

(b)

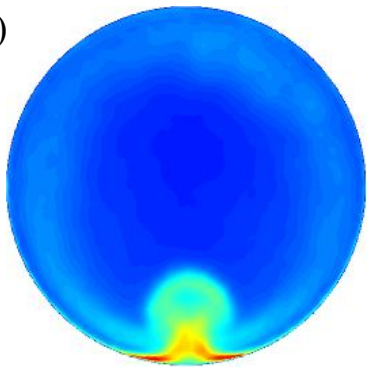

(c)

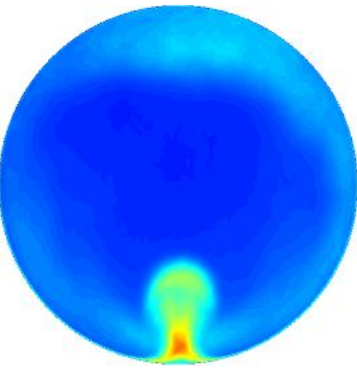

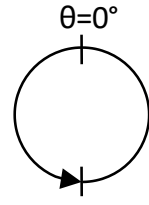

$\pm 180^{\circ}$

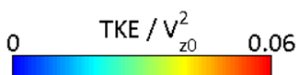

Fig. 6 Contour of turbulent kinetic energy in a cross section of the elbow outlet, (a) $R e=4.5 \times 10^{4}$, (b) $R e=1.8 \times 10^{5}$, (c) $R e=5.4 \times 10^{5}$.

(a)

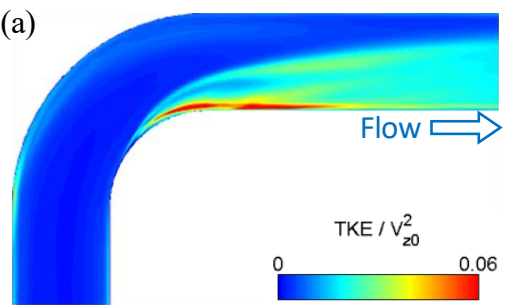

Fig.7 Contour of turbulent kinetic energy in a mid-plane of the elbow, (c) $R e=5.4 \times 10^{5}$.

(b)

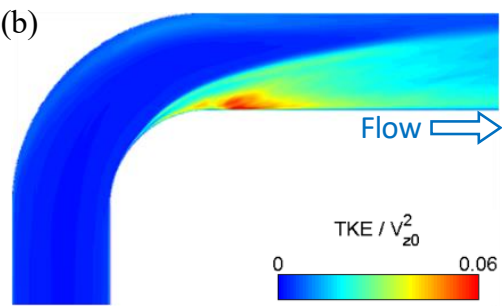

(c)

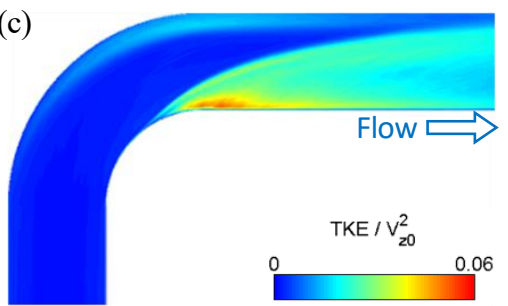

(a) $R e=4.5 \times 10^{4}$, (b) $R e=1.8 \times 10^{5}$,

\section{$3 \cdot 4$ 平均温度分布}

図 8 に時間平均した温度のコンターを示す. 平均温度 $\Theta_{t}$ は入口管軸中心で求めたバルク温度 $\Theta_{t b}$ との温度差を とり, 壁面とバルクの温度差 $\left(\Theta_{t w}-\Theta_{t b}\right)$ により無次元化している. 平均温度はおおよそ流れ方向の平均流速と対 称な分布となる。エルボ出口からエルボ下流にかけて，背側への高速領域の偏流が強くなる領域において，比較 的低温の流体が背側の壁面方向へ偏って存在している. 一方，エルボ腹側では，流れの剥離の後流の低速領域に おいて，流体の平均温度が高くなっている。このエルボ腹側の低速領域は，レイノルズ数の増加にともない空間 的な広がりが縮小するが, 流動場の変化にあわせて平均温度が高くなる領域も小さくなる.ただし，エルボ出口 ではレイノルズ数が低い場合により広い範囲で温度が上昇するが, エルボ通過後にその差異は小さくなる.また, エルボ腹側における平均温度の上昇幅もレイノルズ数への依存性は小さい. 

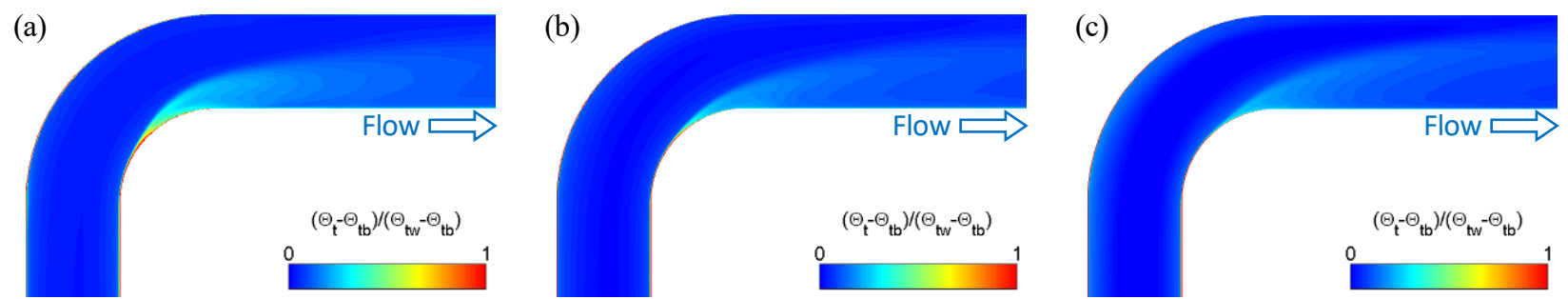

Fig.8 Contour of mean temperature in a mid-plane of the elbow, (a) $\operatorname{Re}=4.5 \times 10^{4}$, (b) $\operatorname{Re}=1.8 \times 10^{5}$, (c) $\operatorname{Re}=5.4 \times 10^{5}$.

\section{$3 \cdot 5$ 熱伝達率に基づくエルボ管の形状係数}

熱伝達率 $h$ 基づく形状係数 $h / h_{0}$ のコンターを図 9 に示す. 図中の左側にはエルボ管の背側と腹側からの俯瞰 図，右側には壁面の展開図を示す．図 10 にはレイノルズ数を変えた場合の背側 $\left(\theta=0^{\circ}\right)$ と側壁 $\left(\theta=90^{\circ}\right)$ と腹側 $\left(\theta=180^{\circ}\right)$ の線上における形状係数分布を示寸. $R e=4.5 \times 10^{4}$ における分布をみると，エルボ内の背側を中心と して形状係数の值が高い領域と, エルボ腹側出口を中心として值が高い領域が広がっていることがわかる. 図 10 には, $R e=4.5 \times 10^{4}$ の条件において電気化学的手法により直接的に物質移行係数 $k_{c}$ を測定して求めた形状係数 $k_{c} / k_{c 0}$ (恒吉他, 2017)をあわせて示した. 背側 $\left(\theta=0^{\circ}\right.$ )では計算值は実験值に対して形状係数を過大評価する傾向 がみとめられるが，側壁 $\left(\theta=90^{\circ}\right)$ と腹側 $\left(\theta=180^{\circ}\right)$ の分布はよく一致している.また，腹側における形状係数の 最大值を比較すると，実験值の方が計算值よりも高い值を示しているが，その差はわずかであり温度場計算によ って乱流スカラー輸送の効果を適切に反映した形状係数を算出できていると考えられる.

レイノルズ数の増加に対して，エルボ管の形状係数は概齐減少する傾向にある. 特にエルボ内の背側では大幅 な形状係数の減少が確認できる.ただし，レイノルズ数が増加すると，背側の形状係数の最大值はエルボの下流 に表れるようになる．これは，エルボ背側の形状係数の増加が，主に流れ方向流速の偏りによって生じており， 図 3, 4 に示したように, レイノルズ数が増加するとエルボ内ではなくエルボ通過後に背側への偏流が強くなるた めである. 腹側の分布をみると, 出口周辺の形状係数が高い領域は, レイノルズ数の増加に対して空間的な広が

(a)
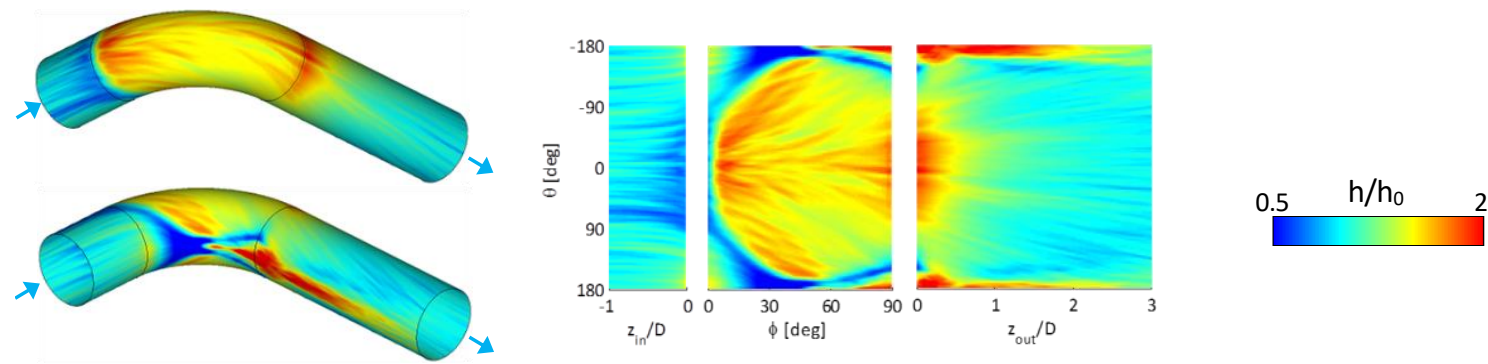

(b)
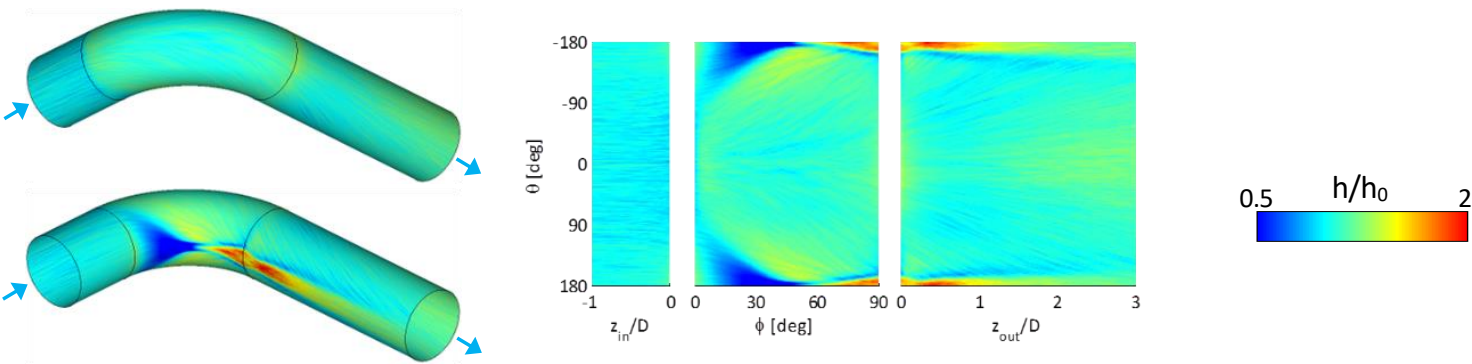

(c)
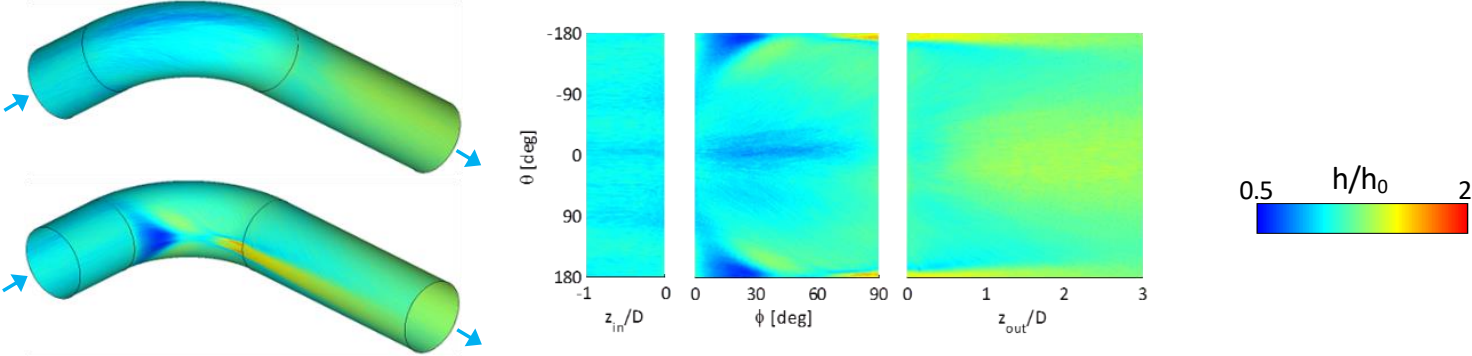

Fig.9 Contour of geometry factor obtained from heat transfer coefficient, (a) $R e=4.5 \times 10^{4}$, (b) $R e=1.8 \times 10^{5}$, (c) $R e=5.4 \times 10^{5}$. 
(a)

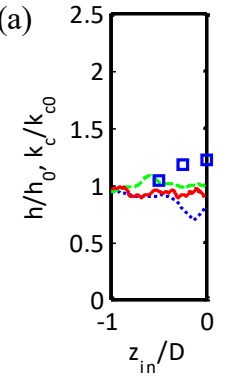

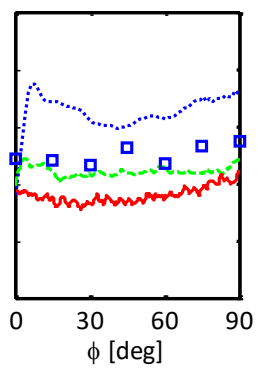

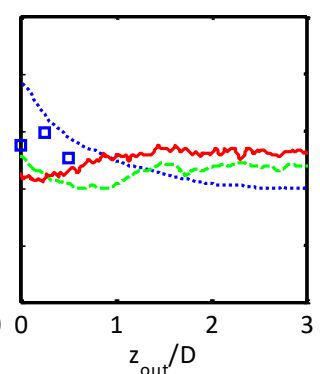

(b)
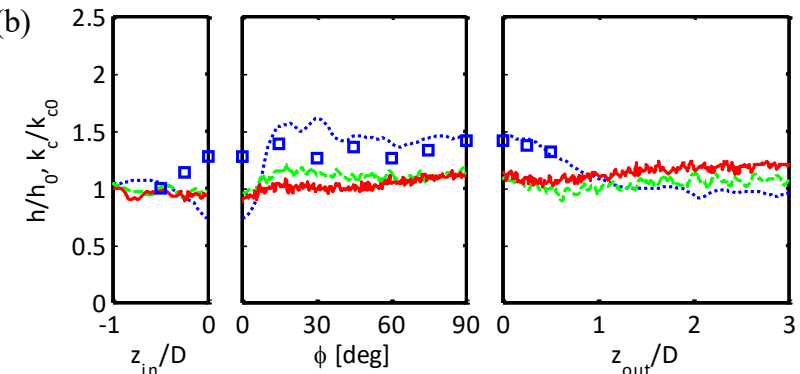

(c)

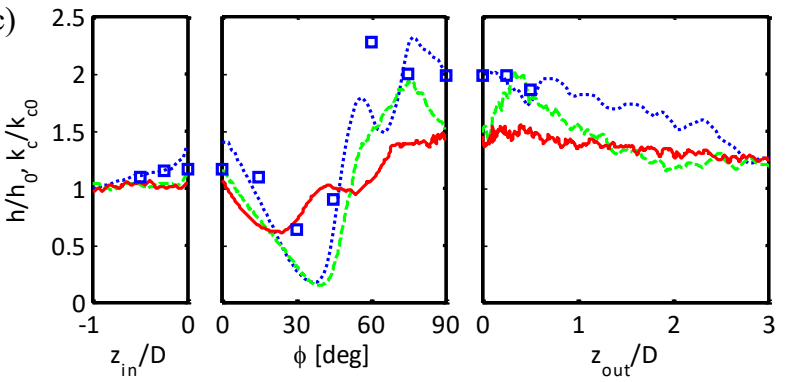

Fig.10 Profile of geometry factor for streamwise direction at several circumferential angles, (a) $\theta=0^{\circ}$, (b) $\theta=90^{\circ}$, (c) $\theta=180^{\circ}$. Lines are present numerical simulation results obtained from heat transfer coefficient for high Reynolds number, ............... : $R e=4.5 \times 10^{4}, \cdots: R e=1.8 \times 10^{5},-\square: R e=5.4 \times 10^{5}$. Symbols $(\square)$ are experimental values from mass transfer coefficient measured by electrochemical method for $R e=4.5 \times 10^{4}$ (Tsuneyoshi et al., 2017).

りが減少し，值も小さくなる。この腹側出口の形状係数は，乱流エネルギーの分布に強く依存しており，形状係 数の減少は速度変動によるスカラー輸送が弱まるためと考えられる．ただし，いずれのレイノルズ数においても 形状係数の最大值は腹側出口の近くに存在しており, $R e=4.5 \times 10^{4}, 1.8 \times 10^{5}, 5.4 \times 10^{5}$ に対して $h_{\max } / h_{0}=$

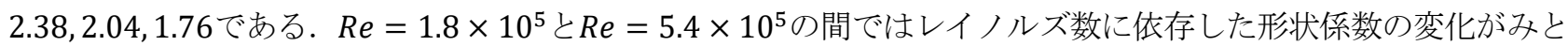
められるが，圧力損失係数のレイノルズ数依存性を考慮すると，さらにレイノルズ数を増加させた際の形状係数 の変化は緩やかになると考えられる.また, 形状係数の最大值のレイノルズ数依存性は単調減少する傾向にあり, さらにレイノルズ数を増加させた際にその傾向から転じて急激に形状係数が増加する危険性は低いと考えられる.

\section{$3 \cdot 6$ 壁垂直方向のスカラー輸送}

エルボ管における複雑流動と壁面の形状係数の増減について解析を行ってきたが，ここから，伝達現象の本質 である流動場中のスカラー輸送について考察する．強制対流熱伝達では乱流による熱輸送が強く働くが，壁面境 界における熱の移動はあくまでも熱伝導である。また，壁面近傍の流動場には粘性の影響を強く受ける粘性底層 が存在しており, 温度場においても熱伝導が支配的な伝導底層を通して熱輸送が行われる. 熱伝達現象において, 複雑流動がこの熱輸送の過程にどのように影響を及ぼしているかという点は非常に重要である.

図 11 に壁垂直方向の熱流束分布を示す. 実線は熱伝導による熱流束, 破線は乱流の速度変動による熱流束をそ れぞれ表す. 熱伝導による壁垂直方向の熱流束 $q_{v i s}=\alpha\left(d \Theta_{t} / d r\right)$ は温度拡散率 $\alpha$ と平均温度勾配の積であり, 乱流 熱流束 $q_{t u r b}=-\overline{v_{r}{ }^{\prime} \theta_{t}{ }^{\prime}}$ は速度変動 $v_{r}{ }^{\prime}$ と温度変動 $\theta_{t}{ }^{\prime}$ の積の時間平均值である. 縦軸の熱流束は, ドライバーの円管 発達乱流における摩擦速度 $u_{\tau 0}$ と摩擦温度 $t_{\tau 0}$ により無次元化している. 横軸は壁面からの距離を摩擦速度 $u_{\tau 0}$ を用 いて無次元化して対数でプロットしている. $u_{\tau 0}$ と $t_{\tau 0}$ の壁変数を用いて無次元化することで，異なるレイノルズ 数のエルボ管流れにおける熱流束の相対的な増減を比較することができる. 円管発達乱流(図 11(a))においては, レイノルズ数の増加に対して，主流部の乱流熱流束が支配的な領域が広くなるが，壁面近傍の熱伝導と乱流熱流 束の分布は変化しない. エルボ背側出口(図 11(b))では, 壁面近傍の乱流熱流束は円管発達乱流に比べて減少する が，熱伝導は増加している。これは，乱れの少ない主流部の高速領域が，エルボ背側への偏流となっていること に対応している. 特にRe $=4.5 \times 10^{4}$ の熱伝導の増加は著しい. エルボ背側出口の熱流束分布から，壁面から離 れた位置における乱流熱流束の増加は, 熱伝達に大きくは影響を及ぼさないことがわかる. エルボ腹側入口(図 11(c))では, $R e=4.5 \times 10^{4}$ においてわずかに熱伝導と乱流熱流束の増加が確認できるが, 高レイノルズ数条件で は円管発達乱流の熱流束分布と大きな違いはみとめられない. エルボ腹側出口(図 11(d))では, 乱流熱流束が壁面 
近傍まで比較的に大きな值を持っている．腹側出口の壁面近傍は速度せん断が強くないが，伝導底層の上部で大 きな乱流熱流束が生じているため，相応に熱伝導も大きくなっている．レイノルズ数が高くなると，乱流熱流束 の最大值は低下寸るが，壁面近傍の乱流熱流束の減少は緩やかである.

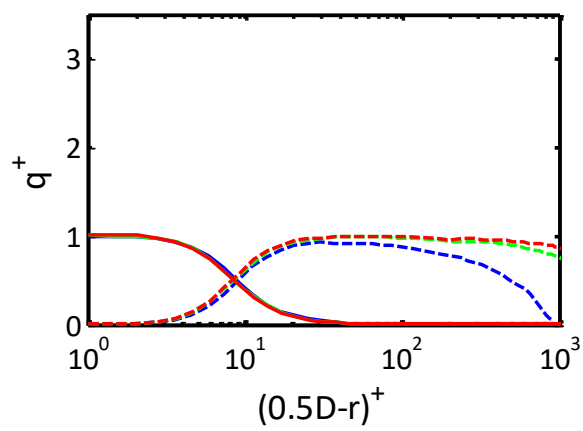

(a) fully developed flow (driver)

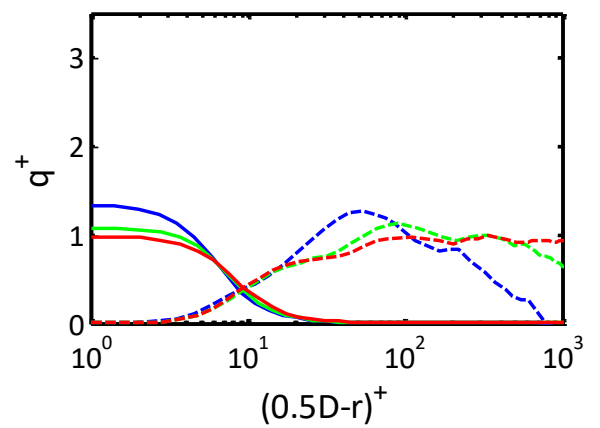

(c) elbow inlet of inner side $\left(\Phi=0^{\circ}, \theta=180^{\circ}\right)$

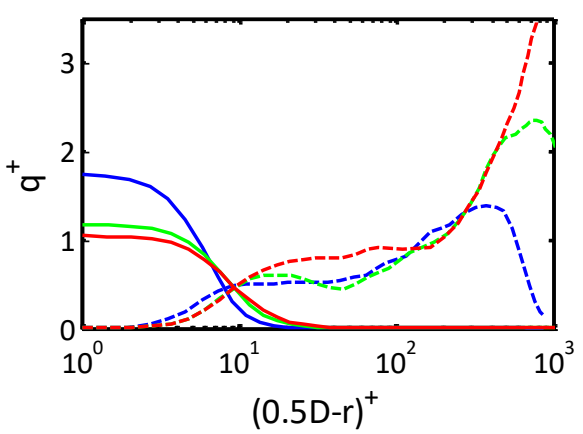

(b) elbow outlet of outer side $\left(\Phi=90^{\circ}, \theta=0^{\circ}\right)$

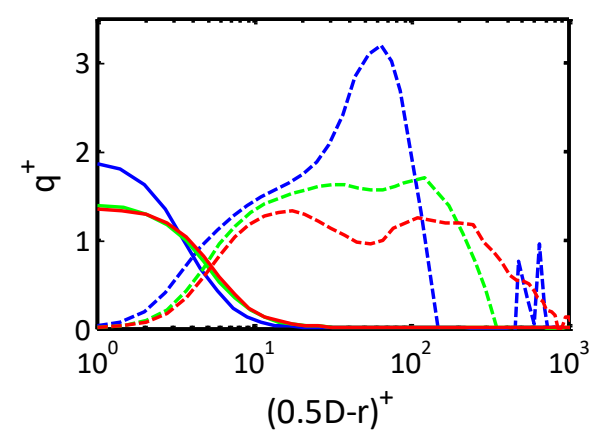

(d) elbow outlet of inner side $\left(\Phi=90^{\circ}, \theta=180^{\circ}\right)$

Fig.11 Distributions of the wall normal heat flux. Solid lines are heat conduction $q_{v i s}=\alpha\left(d \Theta_{t} / d r\right)$ and dashed lines are turbulent heat flux $q_{t u r b}=-\overline{v_{r}{ }^{\prime} \theta_{t}{ }^{\prime}}$. Both heat fluxes are normalized by the friction velocity $u_{\tau 0}$ and the friction temperature $t_{\tau 0}$ in the driver. The color of the line represents Reynolds number (blue: $R e=4.5 \times 10^{4}$, green: $R e=$ $1.8 \times 10^{5}$, red: $R e=5.4 \times 10^{5}$ ). At the elbow outlet of inner side, turbulent heat flux strongly affects the wall heat transfer.

\section{$3 \cdot 7$ エルボ管流れで生じる渦構造と乱流スカラ一輸送}

熱伝達を大きく増加させる要因として, 流動場中の渦構造に注目寸る. 図 10 に速度勾配テンソルの第 2 不変 量 $Q$ の等值面により可視化した渦構造を示寸. 異なるレイノルズ数の条件に対して, $Q$ 值は円管発達乱流におけ る摩擦速度 $u_{\tau 0}$ を用いて無次元化した值 $Q^{+}\left(=Q v^{2} / u_{\tau 0}{ }^{4}\right)$ が等しくなるようにしている. 可視化した渦は比較的強 度の高い渦であるが，主にエルボの腹側で生じていることがわかる．エルボ内では，強い 2 次流れの成分を含ん だ旋回流に沿って，流れ方向に伸びた渦が生じている．エルボ腹側出口では，流れ方向に伸びていた渦が湾曲 し，下流に進むにつれて壁面近傍から主流部へと離脱していく．腹側出口周辺の渦構造は，レイノルズ数の増加 に対して，渦が発生する空間的な広がりは小さくなるが，同程度の強度の渦が発生していると考えられる.

エルボ腹側の渦構造と乱流熱流束の関係について考察する. 図 12 に腹側出口周辺の瞬時の温度場と乱流熱流 束を示す. 乱流熱流束一 $v_{r}{ }^{\prime} \theta_{t}{ }^{\prime}$ は壁面の熱伝達を促進する効果のある $\operatorname{sweep}\left(v_{r}{ }^{\prime}>0, \theta_{t}{ }^{\prime}<0\right)$ と ejection $\left(v_{r}{ }^{\prime}<0, \theta_{t}{ }^{\prime}>\right.$ 0)の成分をそれぞれ寒色と暖色で示している. sweep と ejection は壁乱流におけるレイノルズ応力に対して用いら れている用語であるが，ここでは現象の相似性から乱流熱流束に対して同様に適用する. 腹側出口周辺は剥離流 れの背後の低速領域にあたり, 温度は剥離流れの主流部と比較して高くなっている. 剥離流れに沿った低温流体 と高温流体の境目では, sweep と ejectionの両方が強く働いている.ただし, 壁面から離れた位置の乱流熱流束の 増加は，壁面の熱伝達には直接的には影響を及ぼさない，熱伝達に強く働くのは壁面近傍にみられる ejection に よる熱輸送である.この ejection を主とする乱流熱流束は, 図 12 に示した強度の高い渦によりもたらされている と考えられる. $R e=4.5 \times 10^{4}$ においては，壁面近傍で生じる渦の長さスケールが相対的に大きいため，壁面近 傍の渦による熱輸送と剥離流れに沿った境界での熱輸送の構造を明確に区別することが困難である.レイノルズ 
数が増加すると，相対的に壁面近傍の渦の長さスケールは小さくなり，剥離流れの境界で生じる乱流熱流束と， 壁面近傍での ejection が明確に識別できるようになる．この ejection による熱輸送が強く働くことにより，エルボ 出口腹側は壁面近傍の平均温度が比較的高くなるのにも関わらず，壁面で高い熱伝達率を示すと考えられる。
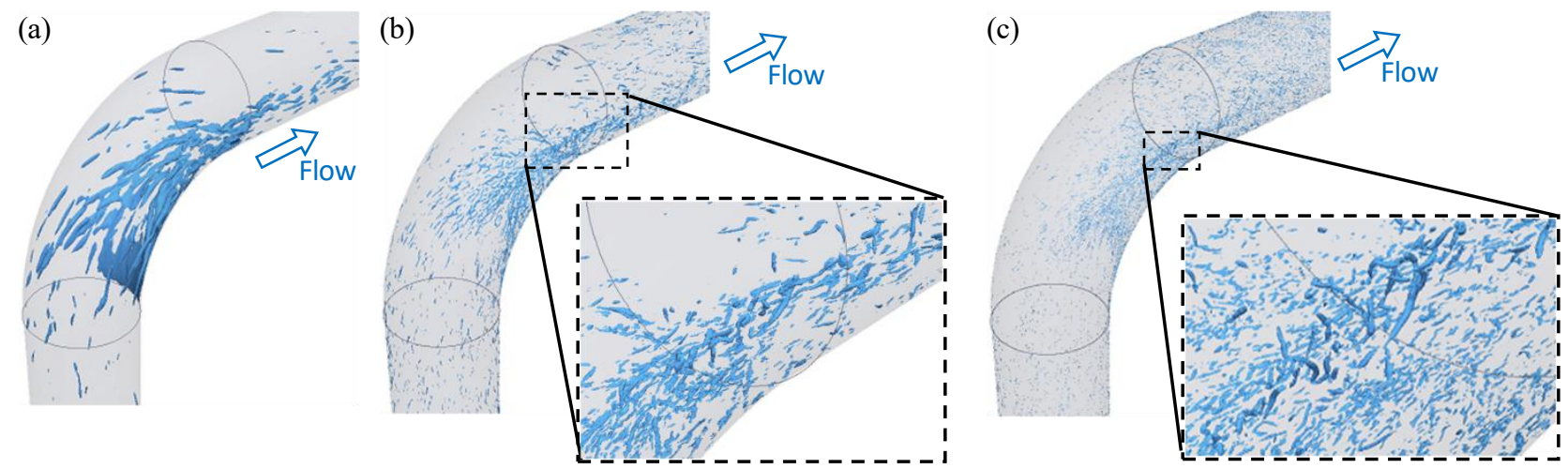

Fig.12 Isosurface of the instantaneous $Q$ criterion $\left(Q^{+}=Q v^{2} / u_{\tau 0}^{4}=0.0028\right.$ ), (a) $\operatorname{Re}=4.5 \times 10^{4}$, (b) $R e=1.8 \times 10^{5}$, (c) $R e=5.4 \times 10^{5}$. Vortex structures leave from the wall to the bulk at the elbow outlet of inner side.
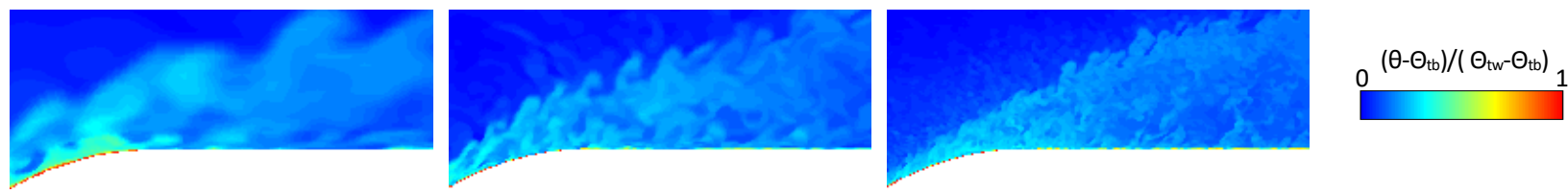

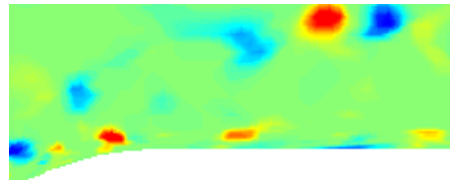

(a) $R e=4.5 \times 10^{4}$

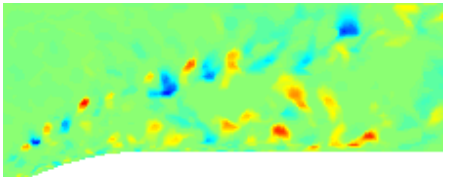

(b) $R e=1.8 \times 10^{5}$

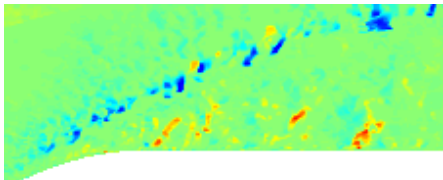

(c) $R e=5.4 \times 10^{5}$

Fig.13 Contour of instantaneous temperature and turbulent heat flux of sweep and ejection component near the elbow outlet of inner side. Turbulent heat flux $-v_{r}^{\prime} \theta_{t}{ }^{\prime}$ are nondimensionalized by $V_{z 0}\left(\Theta_{t w}-\Theta_{t b}\right)$.Turbulent heat flux of $\operatorname{sweep}\left(v_{r}^{\prime}>0, \theta_{t}{ }^{\prime}<0\right)$ and ejection $\left(v_{r}^{\prime}<0, \theta_{t}{ }^{\prime}>0\right)$ contribute to the increase of the wall heat transfer. Near wall region, ejection component works effectively.

\section{4. 結 論}

曲率半径が $R_{C} / D=1.5$ の 90 度エルボ管流れを対象に, 流れ加速型腐食に対する形状係数の導出を目的として, $R e=4.5 \times 10^{4}$ に加えて, 高レイノルズ数条件として $R e=1.8 \times 10^{5}, 5.4 \times 10^{5}$ において LES 計算を行った. 壁面 近傍の微細な渦構造まで解像する LES 計算を行うために，最大で約 5.87 億セルのヘキサメッシュを設定し，計 算コードに OpenFOAM を用いて大規模並列計算を実施した. 流動場計算とともに，鉄イオンの濃度場を模擬し たパッシブスカラーとして温度場計算を行い，熱伝達率に基づく形状係数を算出した。また，流動場と熱輸送の 解析から以下の結論を得た。

流れ方向平均流速について，レイノルズ数の増加に対して，エルボ内での高速領域の偏りは弱まる.これによ り，エルボ背側壁面の熱伝達率に基づく形状係数はレイノルズ数の増加とともに減少する. エルボの腹側出ロで は，壁面近傍で流れ方向に伸びていた強度の高い渦が湾曲し，下流に進むにつれて壁面近傍から主流部へと離脱 していく．この渦構造により高温流体の吹き上げによる強い乱流熱流束が生じ，壁面の熱伝達率も増加する．レ イノルズ数の増加により，壁面近傍の強い渦が発生する領域は狭まり，壁面の形状係数もわずかに減少する．形 状係数は腹側出口の近くで最大值をとり, $R e=4.5 \times 10^{4}, 1.8 \times 10^{5}, 5.4 \times 10^{5}$ に対して $h_{\max } / h_{0}=$ 2.38, 2.04, 1.76である.さらにレイノルズ数が高い条件に対して, エルボ管流れのレイノルズ数依存性を考慮する と, 形状係数は $R e=5.4 \times 10^{5}$ における值から大きくは変化しないと推定される. 


\section{文献}

Dooley, R. B. and Chexal, V. K., Flow-accelerated corrosion of pressure vessels in fossil plants, International Journal of Pressure Vessels and Piping, Vol.77, No.2-3 (2000), pp.85-90.

Germano, M., Piomelli, U., Moin, P. and Cabot, W. H., A dynamic subgrid-scale eddy viscosity model, Physics of Fluids A, Vol.3, No.7 (1991), pp.1760-1765.

岩本幸治, 南浦弘尚, 十河基介，山野秀将，高レイノルズ数域における曲率の強いエルボ内流れの LDV 計測，日 本機械学会論文集 B 編, Vol.76, No.765 (2010), pp.830-838.

河村勉, 中尾俊次, 高橋正典, エルボ下流の乱れに及ぼすレイノルズ数の影響, 日本機械学会論文集 B 編, Vol.68, No.667 (2002), pp.645-651.

森西洋平，市川明洋，奥村隆，中林功一，壁乱流の LES における差分精度と格子解像度の影響，日本機械学会論 文集 B 編, Vol.66, No.647 (2000), pp.1750-1757.

Ono, A., Kimura, N., Kamide, H. and Tobita, A., Influence of elbow curvature on flow structure at elbow outlet under high Reynolds number condition, Nuclear Engineering and Design, Vol.241, No.11 (2011), pp.4409-4419.

OpenCFD, OpenFOAM: The open source computational fluid dynamics(CFD) toolbox, available from $<$ http://www.openfoam.com>, (accessed on 26 May, 2015).

Roe, P. L., Some contributions to the modeling of discontinuous flows, Lectures in Applied Mathematics, Vol.22 (1985), pp.163-193.

Shiraishi, T., Watakabe, H., Sago, H., Konomura, M., Yamaguchi, A. and Fujii, T., Resistance and fluctuating pressures of a large elbow in high Reynolds numbers, Journal of Fluids Engineering, Vol.128, No.5 (2006), pp.1063-1073.

Tanaka, M. and Ohshima, H., Numerical investigation on large scale eddy structure in unsteady pipe elbow flow at high Reynolds number conditions with large eddy simulation approach, Journal of Power and Energy Systems, Vol.6, No.2 (2012), pp.210-228.

日本機械学会，配管減肉管理法の改良・実用化に向けた調査研究分科会成果報告書, P-SCCII-4 (2014).

恒吉達矢, 伊藤高啓, 歌野原陽一, 辻義之, 形状係数測定における壁面伝達境界条件が及ぼす影響に関する研究, 日本機械学会論文集, Vol.83, No.847 (2017), DOI:10.1299/transjsme.16-00417.

Vester, A. K., Örlü, R. and Alfredsson, P. H., Turbulent flows in curved pipes: recent advances in experiments and simulations, Applied Mechanics Reviews, Vol.68, No.5 (2016), 050802.

結城和久, 熊野孝保, 戸田三朗, 橋爪秀利, 村松壽晴, $90^{\circ}$ ベンドで発生する二次流れの非定常減衰挙動, 日本機 械学会論文集 B 編, Vol.70, No.693 (2004), pp.1163-1170.

\section{References}

Dooley, R. B. and Chexal, V. K., Flow-accelerated corrosion of pressure vessels in fossil plants, International Journal of Pressure Vessels and Piping, Vol.77, No.2-3 (2000), pp.85-90.

Germano, M., Piomelli, U., Moin, P. and Cabot, W. H., A dynamic subgrid-scale eddy viscosity model, Physics of Fluids A, Vol.3, No.7 (1991), pp.1760-1765.

Iwamoto, Y., Minamiura, H., Sogo, M. and Yamano, H., LDV measurements of a flow in a strongly-curved elbow under a high Reynolds number condition, Transactions of the Japan Society of Mechanical Engineers, Series B, Vol.76, No.765 (2010), pp.830-838 (in Japanese).

Kawamura, T., Nakao, T. and Takahashi, M., Reynolds number effect on turbulence downstream from elbow pipe, Transactions of the Japan Society of Mechanical Engineers, Series B, Vol.68, No.667 (2002), pp.645-651 (in Japanese).

Morinishi, Y., Ichikawa, A., Okumura, T. and Nakabayashi, K., Effects of the order of accuracy of finite-difference method and grid resolution on LFS of wall turbulence, Transactions of the Japan Society of Mechanical Engineers, Series B, Vol.66, No.647 (2000), pp.1750-1757 (in Japanese).

Ono, A., Kimura, N., Kamide, H. and Tobita, A., Influence of elbow curvature on flow structure at elbow outlet under high Reynolds number condition, Nuclear Engineering and Design, Vol.241, No.11 (2011), pp.4409-4419.

OpenCFD, OpenFOAM: The open source computational fluid dynamics(CFD) toolbox, available from $<$ http://www.openfoam.com>, (accessed on 26 May, 2015).

Roe, P. L., Some contributions to the modeling of discontinuous flows, Lectures in Applied Mathematics, Vol.22 (1985), pp.163-193.

Shiraishi, T., Watakabe, H., Sago, H., Konomura, M., Yamaguchi, A. and Fujii, T., Resistance and fluctuating pressures of a 
large elbow in high Reynolds numbers, Journal of Fluids Engineering, Vol.128, No.5 (2006), pp.1063-1073.

Tanaka, M. and Ohshima, H., Numerical Investigation on large scale eddy structure in unsteady pipe elbow flow at high Reynolds number conditions with large eddy simulation approach, Journal of Power and Energy Systems, Vol.6, No.2 (2012), pp.210-228.

The Japan Society of Mechanical Engineers, Research committee on improvement and practical use of pipe-wall-thinning management, P-SCCII-4 (2014) (in Japanese).

Tsuneyoshi, T., Ito, T., Utanohara, Y. and Tsuji, Y., Study on effects of wall mass transfer condition for measurement of geometry factor, Transactions of the JSME (in Japanese), Vol.83, No.847 (2017), DOI:10.1299/transjsme.16-00417.

Vester, A. K., Örlü, R. and Alfredsson, P. H., Turbulent flows in curved pipes: recent advances in experiments and simulations, Applied Mechanics Reviews, Vol.68, No.5 (2016), 050802.

Yuki, K., Kumano, T., Toda, S., Hashizume, H. and Muramatsu, T., Unsteady decay behaviour of secondary flow generated in 90-degee bends, Transactions of the Japan Society of Mechanical Engineers, Series B, Vol.70, No.693 (2004), pp.11631170 (in Japanese). 